\title{
Microcephaly caused by congenital Zika virus infection and viral detection in maternal urine during pregnancy
}

\author{
Vanessa Couras Regadas ${ }^{1,2}$, Márcio de Castro e Silva ${ }^{1,2}$, Lucas Giansante Abud ${ }^{2}$, Luiz Mario Pereira Lopes Labadessa ${ }^{1,2}$, \\ Rafael Gouvêa Gomes de Oliveira ${ }^{1,2}$, Cecília Hissae Miyake² ${ }^{2}$ Rodolfo Mendes Queiroz ${ }^{1,2 *}$ (i) \\ ${ }^{1}$ Department of Radiology and Medical Imaging, Documenta - Hospital Materno Infantil Sinhá Junqueira, Ribeirão Preto, SP, Brazil \\ ${ }^{2}$ Department of Radiology and Medical Imaging, Documenta - Hospital São Francisco, Ribeirão Preto, SP, Brazil
}

\begin{abstract}
SUMMARY
Study conducted at Documenta -

Centro Avançado de Diagnóstico por Imagem, Hospital São Francisco, Ribeirão Preto, SP, Brazil

Article received: $4 / 21 / 2017$ Accepted for publication: 5/7/2017

*Correspondence: Address: Rua Bernardino de Campos, 980, Centro Ribeirão Preto, SP - Brazil Postal code: 14015-130 rod_queiroz@hotmail.com

Currently Latin America is undergoing a major epidemic of Zika virus, which is transmitted by Aedes mosquitoes. Concern for Zika virus infection has been increasing as it is suspected of causing brain defects in newborns such as microcephaly and, more recently, potential neurological and autoimmune complications including Guillian-Barré syndrome and acute disseminated encephalomyelitis. We describe a case of virus infection in a 25 -year-old woman during the first trimester of her pregnancy, confirmed by laboratory tests only for the detection of viral particles in maternal urine, with imaging studies demonstrating the progression of cranial and encephalic changes in the fetus and later in the newborn, such as head circumference reduction, cerebral calcifications and ventriculomegaly.
\end{abstract}

Keywords: Zika. Virus. Pregnancy. Urine. Microcephaly.

\section{Case report}

Female patient, 25 years old, pregnant with gestational age of 19 weeks and 4 days as per date of the last menstrual period, referred for obstetric morphological ultrasound evaluation. She reported that, between 9 and 11 weeks of gestation, she had episodes of mild fever accompanied by small reddish skin patches and mild pruritus for a week. The patient denied having comorbidities and exposure to teratogenic drugs or substances. Infection with toxoplasmosis, rubella, cytomegalovirus, herpes simplex and syphilis were ruled out based on serum serology. At the end of the symptomatic period, Zika virus (ZIKV) detection was performed using RT-PCR in the patient's urine, yielding a positive result. Maternal serology for ZIKV infection was inconclusive.

Ultrasonographic examination (Figure 1) showed enlarged lateral ventricles, measuring $1.4 \mathrm{~cm}$ on the left and $1.6 \mathrm{~cm}$ on the right, with a biparietal diameter and cephalic perimeter within the expected range, measuring $4.8 \mathrm{~cm}$ and $17.8 \mathrm{~cm}$, respectively, and no other perceptible abnormalities. Gestational age based on biometry was compatible with 21 weeks and 2 days.

Two weeks later, on fetal magnetic resonance imaging (Figure 2), there was a marked lateral ventriculomegaly on both sides associated with significant volume reduction and diffuse thinning of the cerebral parenchyma, with cranial circumference measuring about $19.9 \mathrm{~cm}$.

After 10 weeks, obstetrical ultrasound indicated a fetus with a general measurement compatible with 33 weeks and 3 days, presenting bilaterally enlarged lateral ventricles, biparietal diameter and cranial circumference below the $5^{\text {th }}$ percentile of normality, measuring $6.5 \mathrm{~cm}$ and $22.9 \mathrm{~cm}$, respectively.

Delivery was by cesarean section 6 weeks later. Transfontanelle ultrasonography was performed in the newborn, which demonstrated markedly dilated lateral ventricles, cerebral parenchyma with signs of relevant volume reduction, extensive periventricular calcifications and simplification of the cerebral convolutions (lissencephaly). These findings were confirmed by computerized tomography (Figure 3) on the same day. Serology for Zika virus was not investigated in the newborn.

\section{Discussion}

Latin America is currently undergoing a major epidemic of ZIKV, an arbovirus of the Flaviviridae family and genus Flavivirus transmitted by Aedes mosquitoes, including 


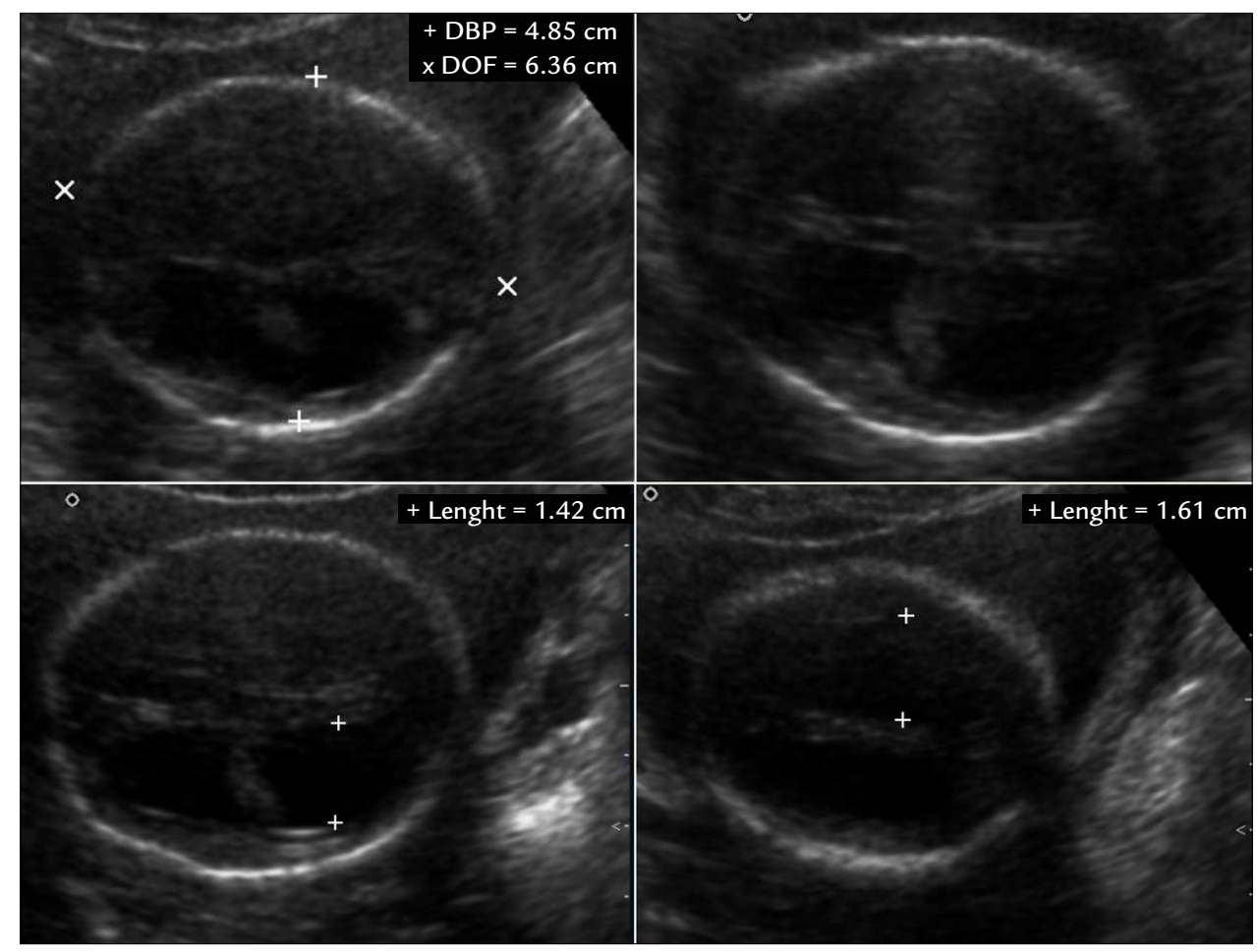

FIGURE 1 Obstetric ultrasonography showing the fetal cephalic pole with enlarged lateral ventricles, and biparietal and occipitofrontal diameters within the expected range.

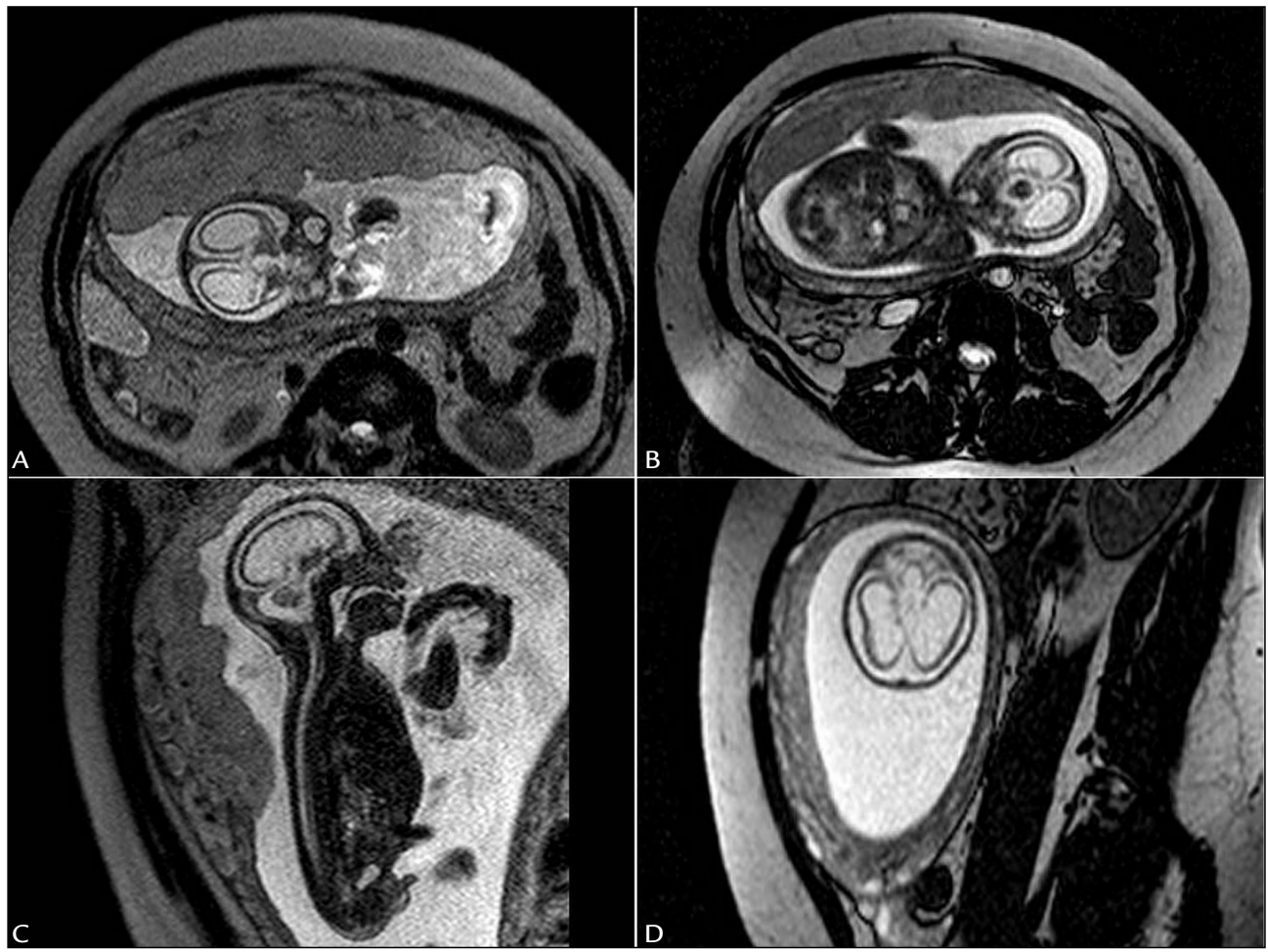

FIGURE 2 Fetal magnetic resonance imaging, T2-weighted sequence demonstrating pronounced lateral ventriculomegaly on both sides associated with significant volumetric reduction and diffuse thinning of the cerebral parenchyma. 

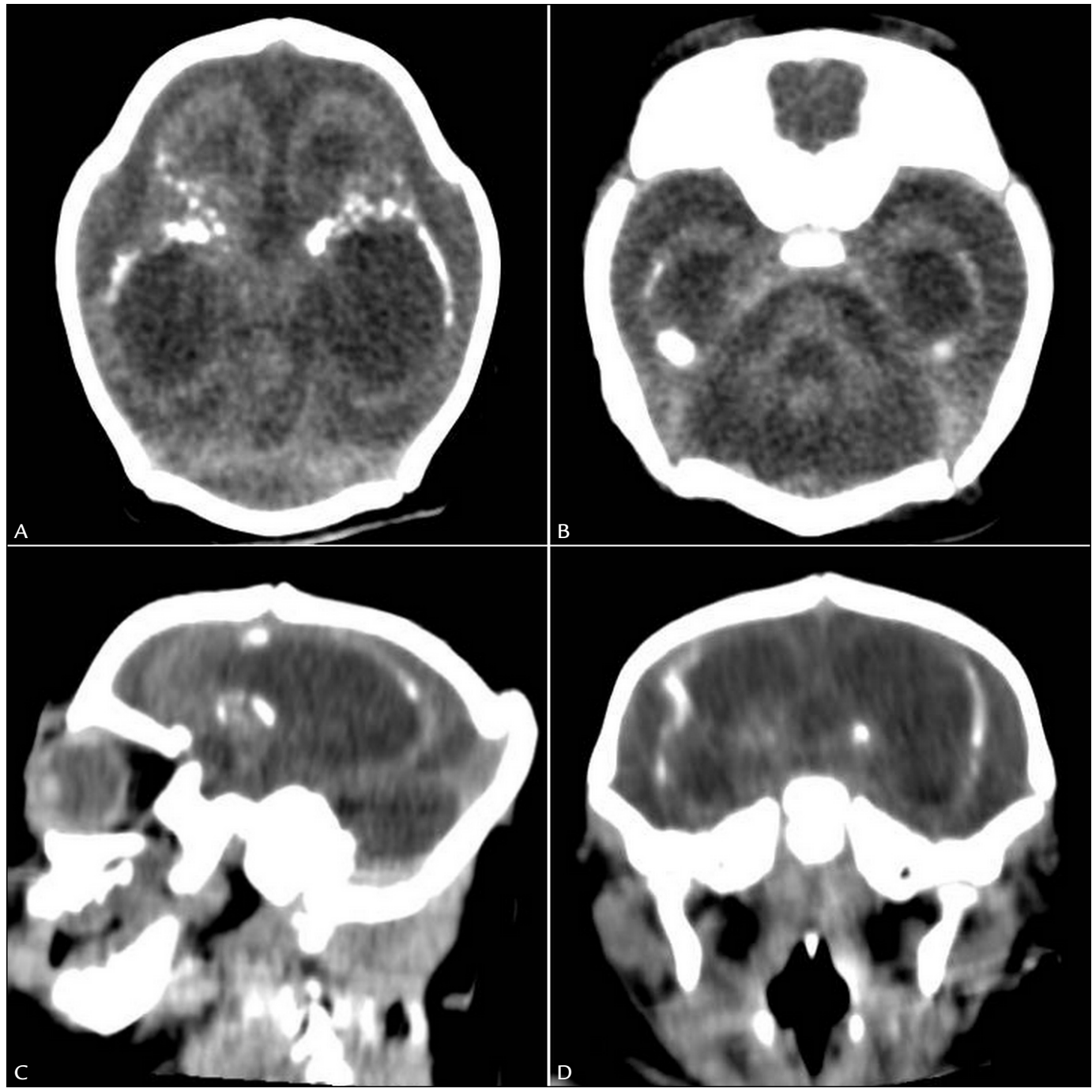

FIGURE 3 Computed tomography of the newborn characterizes markedly dilated lateral ventricles, cerebral parenchyma with signs of marked volumetric reduction, extensive periventricular calcifications and simplification of the cerebral convolutions (lissencephaly).

Aedes aegypti. The name derives from the Zika forest in Uganda, which is where the virus was first isolated in 1947. ${ }^{1}$ Concern for ZIKV infection is increasing, as it is suspected of causing brain defects in newborns, such as microcephaly and, more recently, potential neurological and autoimmune complications such as Guillain-Barré syndrome and acute disseminated encephalomyelitis (ADEM). ${ }^{2}$ According to the World Health Organization (WHO), microcephaly consists of a malformation in which the head circumference is two or more standard deviations smaller than expected for a given gestational age and gender of the newborn. ${ }^{3}$

As of May 2015, several cases of ZIKV infection have been reported in Brazil associated with an increasing number of neonates with congenital microcephaly born to women infected during pregnancy. ${ }^{4}$ Brazil is the most af- fected country, with a preliminary estimate of about 440,000 to 1.3 million autochthonous cases by December 2015. ${ }^{5}$

The infection tends to be benign, with estimated duration of symptoms from 2 to 7 days and include maculopapular rash, fever, arthralgia and conjunctivitis. Myalgia, headache, retro-orbital pain, edema, vomiting, pruritus, dizziness, mucous ulcers, diarrhea and constipation may occur as well. ${ }^{6}$

Diagnosis can be tricky based on clinical signs and symptoms alone, which may overlap with other endemic arboviruses in similar areas. ${ }^{2} \mathrm{~A}$ definitive diagnosis depends on virus isolation or positive polymerase chain reaction (PCR). Serologic testing with IgM antibodies detected by immunoenzymatic (ELISA) or immunofluorescence assay can be performed to diagnose the acute infection. ${ }^{3}$ Identification of ZIKV RNA in amniotic fluid 
in addition to findings of congenital microcephaly assessed on prenatal ultrasonography was reported in two cases of pregnant women. This led to concern about the possible association between congenital microcephaly and the recent outbreak of this infection in Brazil. ${ }^{4}$

RNA detection in urine can occur for longer than the detection in serum after the onset of infection. There are also reports of ZIKV detection in the saliva of neonates and adults. ${ }^{2}$ In a study, Kirsten et al. found a percentage of $62 \%$ of patients evaluated with serum serology negative for ZIKV, but with viral positivity detected in urine, which is meaningful since our case report describes a similar situation. ${ }^{7}$

The radiological findings range from calcifications located predominantly at the junction between the cortical region and the subcortical areas of white matter, malformations of cortical development and sulcation, microcephaly with cortical gyri that present normal thickness associated with areas of thick cortex (polymicrogyria) predominantly located in the frontal lobes, ventriculomegaly with a predominant increase of the posterior portions of the lateral ventricles, abnormalities of the corpus callosum (hypogenesis and hypoplasia) and delayed myelination. ${ }^{8}$

Notably, maternal infection, even if subclinical, can lead to severe congenital abnormalities, and evaluation with serial imaging may demonstrate the progression of the findings. Ultrasonographic findings in prenatal care consist of decreased head circumference and, rarely, increased cranial circumference. The vast majority of newborns will present with more severe calcifications occurring more frequently at the junction of white-gray matter compared to what is usually seen in TORCH infections (toxoplasmosis, rubella, cytomegalovirus and herpes simplex, as well as syphilis, varicella-zoster and parvovirus B1). In the latter, such a location for calcifications is uncommon. Vaccination plays an important role in eradicating fetal disease, but, if immunity is not complete, subsequent exposure to the virus during pregnancy would not prevent infection. ${ }^{1}$

Given that the microcephaly epidemic is a result of congenital Zika virus infection, we recommend that the list of congenital infections referred to as TORCH be renamed to TORCHZ (the letter $Z$ referring to $Z I K V$ ). ${ }^{9}$ Even though it is possible to conclude that there is no radiographic pathognomic pattern of microcephaly caused by ZIKV, gross calcifications and their cortical-subcortical distribution, also involving the basal ganglia, associated with lissencephaly and ventriculomegaly, in the absence of intracranial hypertension, are characteristic of this type of infection. ${ }^{1}$ Advantages of noninvasive collection of urine, saliva, and nasopharyngeal and/or buccal (cheek) samples provide an alternative to diagnose infection in patients whose blood collection may be difficult, including small children, neonates, the elderly, patients with hemorrhagic syndromes and in cases of patient refusal. ${ }^{2}$

\section{Resumo}

Microcefalia causada por infecção congênita pelo Zika virus e detecção viral na urina materna durante a gestação

Atualmente, a América Latina está passando por uma grande epidemia de Zika vírus, transmitido por mosquitos Aedes. A preocupação pela infecção pelo Zika vírus vem aumentando, uma vez que é suspeita de causar defeitos cerebrais em recém-nascidos, como a microcefalia e, mais recentemente, potenciais complicações neurológicas e autoimunes, como síndrome de Guillian-Barré e encefalomielite disseminada aguda. Descrevemos um caso de infecção pelo vírus em uma mulher de 25 anos durante o primeiro trimestre de gestação, confirmado dentre os exames laboratoriais apenas pela detecção de partículas virais na urina materna, com estudos de imagens demonstrando a evolução das alterações cranianas e encefálicas no feto e no recém-nascido, como redução do perímetro cefálico, calcificações cerebrais e ventriculomegalia.

Palavras-chave: Zika. Vírus. Gestação. Urina. Microcefalia.

\section{References}

1. Cavalheiro S, Lopez A, Serra S, Da Cunha A, Costa MD, Moron A, et al. Microcephaly and Zika virus: neonatal neuroradiological aspects. Childs Nerv Syst. 2016; 32(6):1057-60.

2. Lamb LE, Bartolone SN, Kutluay SB, Robledo D, Porras A, Plata M, et al. Advantage of urine based molecular diagnosis of Zika virus. Int Urol Nephrol. 2016; 48(12):1961-6.

3. Sarno M, Aquino M, Pimentel K, Cabral R, Costa G, Bastos F, et al. Progressive lesions of central nervous system in microcephalic fetuses with suspected congenital Zika virus syndrome. Ultrasound Obstet Gynecol. 2016. 50(6):717-22.

4. Hazin AN, Poretti A, Di Cavalcanti Souza Cruz D, Tenorio M, van der Linden A, Pena LJ, et al. Computed tomographic findings in microcephaly associated with zika virus. Engl J Med. 2016; 374(22):2193-5.

5. Mlakar J, Korva M, Tul N, Popović M, Poljšak-Prijatelj M, Mraz J, et al. Zika virus associated with microcephaly. N Engl J Med. 2016; 374(10):951-8.

6. Soares de Souza A, Moraes Dias C, Braga FD, Terzian AC, Estofolete CF, Oliani AH, et al. Fetal infection by zika virus in the third trimester: report of 2 cases. Clin Infect Dis. 2016; 63(12):1622-5.

7. St George K, Sohi IS, Dufort EM, Dean AB, White JL, Limberger R, et al. Zika virus testing considerations: lessons learned from the first 80 real-time reverse transcription-PCR-positive cases diagnosed in New York State. J Clin Microbiol. 2017; 55(2):535-44.

8. Soares de Oliveira-Szejnfeld P, Levine D, Melo AS, Amorim MM, Batista AG, Chimelli L, et al. Congenital brain abnormalities and zika virus: what the radiologist can expect to see prenatally and postnatally. Radiology. 2016;281(1):203-18.

9. Araújo TV, Rodrigues LC, Alencar Ximenes RA, Barros Miranda-Filho D, Montarroyos UR, Melo AP, et al.; investigators from the Microcephaly Epidemic Research Group; Brazilian Ministry of Health; Pan American Health Organization; Instituto de Medicina Integral Professor Fernando Figueira; State Health Department of Pernambuco. Association between Zika virus infection and microcephaly in Brazil, January to May, 2016: preliminary report of a case-control study. Lancet Infect Dis. 2016; 16(12):1356-63. 